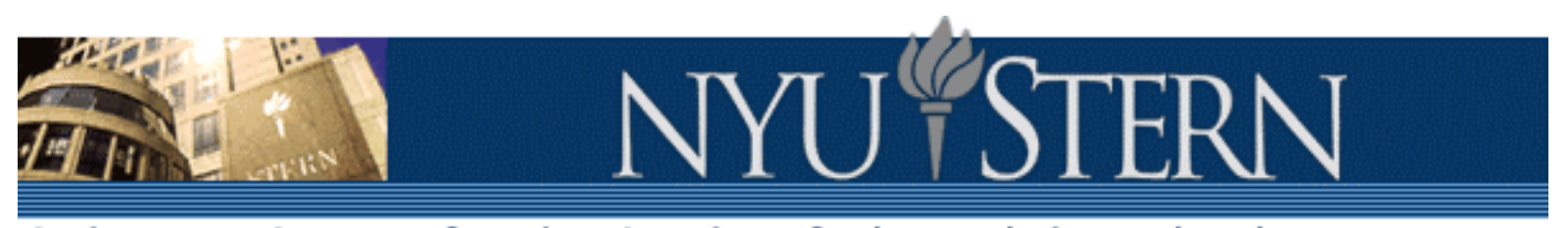

Salomon Center for the Study of Financial Institutions Working Paper Series CREDIT \& DEBT MARKETS Research Group

BIRTH OF THE FEDERAL RESERVE: CRISIS IN THE WOMB

William L. Silber

S-CDM-03-16 
Birth of the Federal Reserve: Crisis in the Womb

\author{
William L. Silber
}

Revised October 2003

The author is the Marcus Nadler Professor of Finance and Economics, Stern School of Business, New York University. He wishes to thank Stephen Cecchetti, Kenneth Garbade, Allan Meltzer, Anna Schwartz, Richard Sylla, Josh Sullivan, Paul Wachtel, and Ingo Walter for helpful comments. Contact information: NYU, Stern School of Business, 44 West $4^{\text {th }}$ Street, New York, N. Y. 10012.

Telephone: 212-998-0714. Email: wsilber@stern.nyu.edu 


\section{Abstract \\ Birth of the Federal Reserve: Crisis in the Womb}

The outbreak of World War I shut the New York Stock Exchange for more than four months. The conventional explanation maintains that the closure prevented a collapse in stock prices that threatened a repetition of the Panic of 1907. This paper shows that the Wilson Administration encouraged the suspension of trading to pave the way for launching the Federal Reserve System, which was in the process of being born. Closing the Exchange helped to forestall an outflow of gold. Federal Reserve insiders considered an adequate stock of gold crucial to the success of the new monetary system.

JEL Classification: E42, N22, E58

Keywords: Federal Reserve, Gold Standard, Financial Crises, World War I 


\section{$\underline{\text { I. Introduction }}$}

A confrontation between systemic risk and market liquidity occurred at the outbreak of World War I, just as the Federal Reserve System was being organized. On July 31, 1914, European investors seemed poised to liquidate their holdings of U.S. stocks and bonds to transfer gold to Europe to pay for the war. Policymakers worried that a stock market crash and gold outflow would cause an economic collapse similar to the consequences of the 1907 bank suspensions. ${ }^{1}$ The crisis called for central bank intervention. The problem was that Congressional hearings on President Wilson's nominations to the Federal Reserve Board were still in progress and the regional Federal Reserve banks had not yet been organized.

How did policymakers respond to the crisis? They shut the New York Stock Exchange (NYSE) on July 31, 1914 to prevent a collapse of stock prices and to help stem the gold outflow. The Exchange remained closed for more than four months, until December $12^{\text {th }}$, despite the United States not yet being a combatant in the war.

Sprague [1915, p. 513], in a follow-up to his classic 1910 study of crises under the National Banking System, applauds the decision to close the Exchange: "If the stock exchange had not closed on Friday, July 31 , it is certain that the decline in the price of securities during the day would have been so extreme as to have occasioned numerous failures of brokers and their customers and presumably much loss to the banks as well." Friedman and Schwartz [1963,

\footnotetext{
${ }^{1}$ A contemporaneous view of the crisis is summarized in Noble [1915, pp.13-4] and Sprague [1915]. More recent perspectives appear in Friedman and Schwartz [1963, p.172], Meltzer [2003, p.82], and Sobel [1968, p.327-331].
} 
p.172] accept Sprague's account of the crisis. Chandler, in his celebrated biography of Benjamin Strong ${ }^{2}$ [1958, p.55], extends Sprague's observation: "A general money panic would almost certainly have occurred if the Exchange remained open with falling security prices, widespread calling of loans collateralized by securities, and large foreign sales increasing the burden of foreign payments."

Sprague's contemporary analysis and Chandler's retrospective articulated what could have happened, but my evidence will demonstrate that the threatened stock market crash evaporated before the end of August. My data also undermine the speculation that stock prices would have collapsed had the New York Stock Exchange been open on July $31^{\text {st }}$.

Why did the Stock Exchange remain closed for more than four months? ${ }^{3}$ I will show that individuals at the Federal Reserve fostered the delay to insure a successful launch of the System. The Federal Reserve Act, signed into law on December 23, 1913, required that gold be held as backing for Federal Reserve Notes. The Fed would not be effective, according to influential insiders, if it were

\footnotetext{
${ }^{2}$ Benjamin Strong became the first Governor of the Federal Reserve Bank of New York in October, 1914. He is considered the most influential member of the Federal Reserve System during its formative years (see Friedman and Schwartz [1963, p.225, 411] and Meltzer [2003, p.193].

${ }^{3}$ The London Stock Exchange and the Paris Bourse suspended normal trading during this period, but, unlike the United States, England and France had already been drawn into the war. The Wall Street Journal [September 28, 1914] indicated that the Bourse remained closed, in part, "because so many exchange members had joined the army." Michie [1999, p.144] makes a similar point when explaining the reasons for London's closing: "Germans were the single most important group of non-British among both members and clerks." Keynes [1915, p. 462] adds that "...the failure of an important firm... who were largely concerned in business with Germany brought home to members of the Stock Exchange the character of the situation." Keynes [p. 461] also notes that Paris faced a logistics problem: "...the Paris Parquet remained...open to a certain extent up to the impending evacuation of Paris by the Government on September $2^{\text {nd }}$."
} 
rushed into existence without sufficient gold. Keeping the Exchange closed helped restrain the gold outflow, paving the way for the new currency system. ${ }^{4}$

President Wilson and Treasury Secretary McAdoo recognized that the United States was in the midst of a major shift in institutional structure. To insure a smooth transition to the new monetary order they agreed to sacrifice stock market liquidity. An effective substitute market emerged after the trading suspension, ${ }^{5}$ although they had no way of knowing that when the decision was made to close the Exchange.

Wilson and McAdoo followed a two-part strategy with respect to the Federal Reserve System. They satisfied their instincts and rushed the Board of Governors into existence to provide wise counsel. They heeded the warnings of gold enthusiasts at the Fed and deferred the opening of the individual Reserve Banks until the horizon cleared.

\section{Countering the Immediate Threat}

Like many crises under the national banking system (see Sprague [1910]), the outbreak of World War I threatened to force banks to suspend the convertibility of deposits into gold if they could not meet their customers' demand for currency. This time it was European investors who would liquidate their dollar denominated securities on the New York Stock Exchange, receive checks drawn on U.S. banks and then demand payment in gold, as was their right under the gold standard. With a fractional reserve system there simply was not enough

\footnotetext{
${ }^{4}$ The regional Federal Reserve banks opened on November 16, almost a month before the reopening of the New York Stock Exchange.

${ }^{5}$ For an extensive discussion of this point, see Silber [2003].
} 
gold to go around. And without a central bank to supply an alternative reserve asset, bank suspensions would trigger a repeat of the economic contraction that followed the Panic of 1907.

On August 1, 1914 the Wall Street Journal reported a three-pronged defense against the financial threat: "President Wilson has taken strong steps to protect the United States against the tremendous financial and commercial pressure caused by the European war. He practically made up his mind to send one and possibly two nominations for the Federal Reserve Board to the senate before the close of the day... He directed Secretary of the Treasury McAdoo to take all possible steps to insure the financial stability of the nation and he approved the closing of the New York Stock Exchange...McAdoo said: 'The Aldrich-Vreeland Act, as amended by the Federal Reserve Act, is still in force...currency may be issued under that act... to meet any emergency."'

Wilson succeeded almost immediately in legislating each part of his crisis management strategy. Of the three components, the relatively obscure AldrichVreeland emergency currency was by far the most important in combating the economic threat, despite Treasury Secretary McAdoo's reference to it [1931, p.214] as "a feeble emergency measure." Closing the Exchange merits an assist but the Federal Reserve System arrived after the battle had been won.

\section{II.1 Aldrich-Vreeland Currency}

The issuance of emergency currency, originally authorized by the AldrichVreeland Act of 1908 and extended by the Federal Reserve Act until June 30, 
1915, was designed precisely to avoid a repetition of the Panic of 1907. According to Friedman and Schwartz [1963, p.441], the Aldrich-Vreeland Act enabled banks "to convert their assets into additional high-powered money," by authorizing groups of banks, known as National Currency Associations, to apply to the U.S. Treasury for emergency currency in exchange for approved bank assets. A number of features of the Act were archaic, especially the provision that the emergency currency could be issued only by banks already having banknotes (currency) outstanding secured by U.S. bonds equal to 40 percent of their capital. In 1914 many large banks had no such currency notes outstanding. ${ }^{6}$

On Tuesday, August $4^{\text {th }}$, Congress amended the terms of the Act to expand its scope and magnitude. The New York Times [August 5,1914] reports: "President Wilson signed the bill amending the Aldrich-Vreeland Emergency Currency Act to provide a practically unlimited supply [my italics] of emergency currency. More than $\$ 1,000,000,000$ may be added. Under the amended bill... banks will be able to issue currency notes equal to 125 percent of the combined capital and surplus of the banks."

The Wall Street Journal reported on August $5^{\text {th }}$ and $6^{\text {th }}$ that $\$ 11$ million of the emergency currency has actually been issued and that " $\$ 100$ million had been shipped to the sub-treasuries in New York, Chicago, St. Louis, Cincinnati, San Francisco, Boston and Philadelphia in order that the needs of the banks may be promptly supplied. In many cases banks have applied for additional currency

\footnotetext{
${ }^{6}$ The Wall Street Journal [August $5^{\text {th }}$ ] reports: "Although a great many banks in New York city have applied for emergency currency, so far the majority have not been able to obtain the notes... [because] they have not the requisite...circulation already outstanding. This applies to the National City Bank among others."
} 
merely as a precautionary measure." At the peak in October, 1914, banks needed less than $\$ 400$ million $^{7}$ out of the one billion dollar allotment.

The speed of the policy response to the perceived emergency no doubt contributed to its success. Crises disappear if they fail to get started. Friedman and Schwartz [1963, p. 196] summarize: "By the time the Federal Reserve Banks opened for business in the middle of November 1914, the country had recovered from the immediate shock of the declaration of war in Europe, thanks in no small part to the availability of Aldrich-Vreeland emergency currency."

\section{II.2 Closing the Stock Market}

If Aldrich-Vreeland currency saved the day, why did the New York Stock Exchange have to close? Despite the decline of 8.05 percent on Thursday, July $30^{\text {th }}$ in the New York Stock Exchange's average of 50 stocks, almost no one expected the NYSE to suspend trading on July $31^{\text {st }}$. On that same morning the front page of the New York Times carried a headline that read: "Bankers Here Confer on War: Closing of Stock Exchange Not Necessary, Meeting at Morgan Offices Decides." The public explanation for the suspension of trading was summarized in the Times the next day (August 1st): "There had been no call for the meeting, and the understanding was that the Exchange would open as usual...but the discovery that the market was loaded down with big selling orders and almost bare of buying orders... alarmed the brokers so much that they hurried upstairs to urge a reconsideration of the decision to remain open."

\footnotetext{
${ }^{7}$ According to Meltzer [2003, p.82], a maximum of $\$ 308$ million was used while Friedman and Schwartz [1963, p.172] put the number at $\$ 364$ million.
} 
We know now, thanks to McAdoo's autobiography [1931, p. 290], that at 9:30 on Friday morning, July $31^{\text {st }}$, J. P. Morgan, Jr. relayed a message to the Governing Board of the New York Stock Exchange from Treasury Secretary McAdoo, suggesting that the NYSE close. According to Henry Noble [1915, pp.11-12], President of the New York Stock Exchange, the Board voted to suspend trading less than fifteen minutes before the scheduled 10am opening bell on that Friday.

Although President Wilson did not legislate the Exchange closing, the Administration obviously did more than just approve it. Moreover, once the Exchange was closed, McAdoo used his influence to keep it shut. As early as August $2^{\text {nd }}$, the New York Times wrote: "It would not surprise officials in Washington if Mr. McAdoo used his influence in New York to keep the New York Stock Exchange closed for some time. No direct proposal of this kind may be made but he is expected to show that the Government does not look kindly upon the reopening of the exchange at this time." Was that because of the "clear and present danger of a stock market collapse' or was it something else?

It must have been something else because the evidence shows:

(1) Stocks probably would not have declined very much had the Exchange remained open on the $31^{\text {st. }} ;(2)$ Even if the uncertainty justified a 'circuit breaker' closure on the $31^{\text {st }}$, the threat of a market collapse was over by the end of August. 


\section{II.2.1 Stock Prices on July 31, 1914}

No one has verified the conventional wisdom, published in the August $1^{\text {st }}$ New York Times, and memorialized by Sprague [1915, p. 513], that brokers experienced an overnight build-up of sell orders to be executed on July $31^{\text {st }}$. The NYSE closed before the opening. However, the Consolidated Stock Exchange ${ }^{8}$, located in New York and trading primarily "odd-lots" of NYSE listed securities opened (as usual) at 9:30 on July $31^{\text {st }}$, but then closed at 10am when the NYSE voted to close.

Table 1 shows the six stocks that traded during that 30 -minute session. Column (1) lists the stock, column (2) lists the July 31 closing price at 10am on the Consolidated Exchange and the percentage change from the NYSE close on July 30 , and column (3) lists the closing price on the NYSE for July 30 and the percentage change from July 29 . All of the stocks showed considerable declines on July $30^{\text {th }}$. In the abbreviated trading session on the Consolidated Exchange on the $31^{\text {st }}$, two stocks rose, two remained unchanged and only two declined. Western Union dropped the most - a decline of 4.4 percent.

European investors probably would not have directed their orders to the Consolidated Exchange. Only a few hundred shares of each stock traded during that first half hour. But the information of a substantial overhang of sell orders on the NYSE should have been reflected in the prices on the Consolidated Exchange. The transactions prices on the Consolidated Exchange fail to confirm rumors of the overnight build-up of sell orders.

\footnotetext{
${ }^{8}$ For the origin of the Consolidated Exchange see Nelson [1907]. Its demise in 1926 is discussed in Sobel [1972].
} 


\section{II.2.2 Stock Prices During August and September}

Evidence that stock prices were stable accumulated during August and September. I have shown (see Silber [2003]) that prices on New Street, the substitute market that traded NYSE listed stocks in the street, were virtually unchanged during the last few days of August compared with the closing prices on July $30^{\text {th }}$. During September prices hovered about $2 \frac{1}{2}$ percent below July $30^{\text {th }}$. Moreover, I have also shown that even though the popular press blacklisted New Street prices, Henry Noble, President of the NYSE, monitored New Street quotes. And if Noble knew that stock prices on New Street were stable, so did Secretary McAdoo.

Although European investors would have found it difficult to transact in New Street because of the absence of clearing facilities, transactions prices on New Street would have reflected war related information, including the threat of European liquidation. ${ }^{9}$ Thus, the stability of stock prices on New Street suggests that if the NYSE had reopened at the end of August the expected deluge of selling would not have materialized. ${ }^{10}$ The Wall Street Journal [September 10, 1914] confirmed that judgment by reporting: "Liquidation of foreign holdings of the shares of United States Steel Corporation during the trying period preceding the closing of the Stock Exchange ${ }^{11}$ was surprisingly small. If the selling of Steel

\footnotetext{
${ }^{9}$ In late October New Street prices declined by about 9 percent compared with July 30 closing prices because of adverse developments in Europe (see Silber [2003] and Noble [1915, p.43]).

${ }^{10}$ By way of contrast, Michie [1999, p.148] reports that unofficial trading in London confirmed that prices on the London Stock Exchange would have fallen dramatically had London re-opened. London remained closed until January 4, 1915.

${ }^{11}$ The 'trying period' refers to the week ending July $31^{\text {st }}$, when the NYSE average of 50 stocks declined by 11.1 percent. There had been rumors that substantial foreign selling of U.S. securities
} 
shares by foreigners can be regarded as a barometer...then the many reports of... [liquidation] have been greatly exaggerated."

If stock prices were relatively stable, why did McAdoo use his influence to keep the Exchange shut? ${ }^{12}$ Part of the answer is that the Exchange could remain closed without creating investor resentment because an effective substitute source of liquidity had emerged. The public could trade on New Street, which offered liquidity to those who needed it (see Noble [1915, pp. 38]). The clamor to re-open the Exchange came from the brokers, ${ }^{13}$ who had lost their livelihood. But to McAdoo that was less important than insuring the successful launch of the safety net of the future - the Federal Reserve. We will see that keeping the Exchange closed helped protect the birth of the new monetary system.

\section{II.3 A Split Opening for the Federal Reserve}

Treasury Secretary McAdoo knew how important the Federal Reserve System could be in dealing with the crisis. On August $1^{\text {st }}$, the New York Times reported: "After a conference with the President, [Treasury] Secretary McAdoo expressed the belief that there should be no further serious delay in getting the

drove down prices. Sprague [1915, p. 508] observed:"...the overwhelmingly large sales of securities by foreign holders on the New York Stock Exchange on Tuesday July 28 and on the two following days." It is surprising that Sprague ignored the U.S. Steel disclosure that few foreigners had liquidated their holdings between June $30^{\text {th }}$ and August $31^{\text {st }}$. According to the Wall Street Journal [September 10, 1914], US Steel was the most widely held U.S. security in Europe. ${ }^{12}$ On August $27^{\text {th }}$ the Wall Street Journal said: “...intimations have been received from Washington to the effect that the opening of the Exchange would be considered undesirable by the Government officials who realize that...every effort should be made to relieve the strain on the country's monetary system." Recall the New York Times' observation on August $2^{\text {nd }}$ that Mr. McAdoo would use his influence to keep the Exchange closed for some time.

${ }^{13}$ Various stock exchanges, representing their brokerage house constituents, regularly called for a resumption of trading during the period of suspension. Noble[1915, p.34] reports that as early as August $5^{\text {th }}$, the Baltimore Stock Exchange urged that trading be resumed. The Wall Street Journal [August 17, 1914] reported that the Consolidated Stock Exchange called a Board meeting to consider steps to trade. 
new reserve bank system fully organized... The international character of the Federal Reserve banks under the new law is broad and flexible in the matter of dealing with gold coin and bullion..."

But McAdoo also knew how much the bankers opposed the new system. He observed [McAdoo, 1931, p.213]: "Bankers fought the Federal Reserve legislation - and every provision of the Federal Reserve Act - with the tireless energy of men fighting a forest fire." ${ }^{14}$ The bankers invoked the crisis of World War I as a delaying tactic. On August $5^{\text {th }}$ the New York Times reported that the general sentiment among bankers was: “...the present is not an auspicious time for the installation of the new banking system."

To get the System going but to avoid unnecessary pitfalls, McAdoo engineered a split opening. The Board was confirmed on August $7^{\text {th }}$, only days after President Wilson rushed the last two nominees -- Paul M. Warburg and Franklyn A. Delano -- before the Senate for approval. After the swearing-in ceremony on August $10^{\text {th }}$ McAdoo said [New York Times, August 11, 1914]: "We are going to be able to make this System a bulwark against financial disaster...These banks could have been organized by the $1^{\text {st }}$ of August, but due to causes over which we had no control the organization was not perfected by that date. The fact that the Board itself has been organized means that the Banks can certainly be organized by the $1^{\text {st }}$ of October, or sooner."

The Federal Reserve Act conferred the right to set the date for opening the regional Banks on the Secretary of the Treasury (see Meltzer [2003, p.74fn]).

\footnotetext{
${ }^{14}$ Chandler [pp.32-6] confirms banker opposition to the Federal Reserve Act. This does not imply that bankers were against the establishment of a central bank in the United States. Rather, they were unhappy with this particular version of the legislation.
} 
McAdoo clearly wanted the banks to open sooner, rather than later.

Nevertheless, the twelve Federal Reserve Banks did not open until November $16^{\text {th }}$. What caused the delay?

\section{The Gold Problem}

On Sunday night, August $2^{\text {nd }}$, McAdoo traveled to New York to meet with leading bankers to hear their views about gold. ${ }^{15}$ In 1914 , gold and foreign exchange were intertwined by the gold standard.

Under the rules of the gold standard, the exchange rate between U.S. dollars and British pounds (Sterling) fluctuated in a narrow range around $\$ 4.8665$ per British pound, the mint parity exchange rate determined by the gold content of the dollar and the pound (see Yeager [1966]). The demand for British pounds versus dollars should never, under normal circumstances, force the exchange rate above the mint parity by more than the cost of shipping gold to London. Under those conditions, it would pay to ship gold to satisfy obligations abroad rather than to buy Sterling above the 'gold export point'.

Estimates of the gold export point varied with shipping costs and insurance. The Wall Street Journal noted [July 31, 1914]: “...the most experienced operator would never have dreamed that any combination of circumstances could have arisen to drive demand sterling to 4.98 , or about ten cents above the ordinary gold export point." Thus the Journal calculated the gold export point at $\$ 4.88$ on July $31^{\text {st }}$, and reports that sterling sold at $\$ 4.98$. On

\footnotetext{
${ }^{15}$ The New York Times [August 3, 1914] reports McAdoo saying: "I came to New York for a conference with leading bankers about the issuance of national bank currency... and for a discussion of measures for the protection of the gold supply of the country.
} 
August $5^{\text {th }}$ the Journal quoted Sterling between "6.25@6.75 ... with practically no business done." 16

As long as Sterling stayed above the gold export point, the pressure to send gold abroad would continue. The Wall Street Journal noted on July 29th "...the engagement of gold on a large scale for shipment to Paris and London." Only the jump in the real cost of shipping gold, because of war related risks, deterred gold exports. ${ }^{17}$ When the Bank of England established a gold depository in Ottawa, Canada, however, everyone knew the shipping barrier disappeared. The New York Times [August $12^{\text {th }}$ ] reported: "Owing to the severe straits into which the war had plunged foreign exchange, the news [about Ottawa] aroused instant opposition among New York financiers."

The disarray in the foreign exchange market hurt business, but what mattered most to bankers was that U.S. obligations were payable either in dollars or in gold. Failure to pay gold, if it were demanded, would cause irreparable damage to the credit worthiness of U.S. corporate and municipal securities. Bankers always worried about credit worthiness, but especially in 1914. Back then bankers had placed many of these securities with their European counterparts. The Europeans would surely demand gold rather than dollars under wartime conditions.

\footnotetext{
${ }^{16}$ Sterling had been above the gold export point beginning with July $27^{\text {th }}$. The Wall Street Journal [July 31, 1914] explains the premium on Sterling as follows: "There was a large short interest in the market when Austria surprised the world by sending her ultimatum to Servia [Serbia], representing those who had sold for future delivery...While there was no immediate necessity for evening up their commitments, the shorts were faced with the possibility that even higher rates would obtain when their obligations fell due." On August $5^{\text {th }}$ the Wall Street Journal continued: "The banks have already sold the exchange against the gold, and unless the metal goes forward...they will be that much 'short' of exchange."

${ }^{17}$ The Wall Street Journal noted on July $31^{\text {st }}$ that the "increase in the cost of insuring gold shipments had raised the gold export point."
} 
Bankers supported the suspension of trading on the New York Stock Exchange and the issuance of Aldrich-Vreeland currency because they both served to conserve gold. ${ }^{18}$ The New York Times said on August $1^{\text {st: }}$ "....the closing of the Exchange put an additional barrier in the way of gold export, and perhaps it was the only means to that end which was at hand." Closing the Exchange would help prevent gold exports even if every potential European seller were met by a domestic U. S. purchaser to produce stable stock prices. European sellers were likely to present checks for payment to domestic U.S. banks and demand gold, the only universally acceptable medium of exchange. ${ }^{19}$ Domestic investors did not represent the same threat to the U.S. gold supply, especially with bank access to Aldrich-Vreeland currency for meeting cash withdrawals. ${ }^{20}$ The New York Times article emphasizes the connection by noting: “...an additional measure of protection for our gold supplies [is the] circulation provided under the Aldrich-Vreeland Act...which will supply any local demand for cash without putting it out in a form that could be immediately taken for export."

Note the specificity of the Aldrich-Vreeland Act. It resolved the problem of a domestic shortage of gold because it provided legal tender within the U.S. but

\footnotetext{
${ }^{18}$ Bankers also supported the suspension of trading because they worried about the impairment of the stock exchange collateral backing their brokers' loans. They were safe as long as prices remained officially frozen at the July 30 closing quotes. Stable New Street prices minimized this problem.

${ }^{19}$ Sprague [1915, p. 510] says: “...the disturbing effect of these [stock exchange] sales was almost wholly due to the fact that they were sales by foreign holders rather than [because of] the quantities offered for sale."

${ }^{20}$ The availability of Aldrich-Vreeland currency also made up for the illiquidity of brokers' loans (the stock exchange collateral could not be sold). Sprague [1915, p.513] says:" The effects upon banks of locking up part of their assets... proved less serious than was at first anticipated." He goes on to say [p.519]: "Thanks again to the emergency notes ...the banks were able to meet requirements for additional loans occasioned by the crisis."
} 
it did not satisfy international requirements. How did the bankers prepare to meet foreign obligations? They formed a gold pool.

\section{III.1 The Gold Pool}

On August $28^{\text {th }}$ the Federal Reserve Board called a conference at the Treasury Department for the following week to discuss "a solution to the foreign exchange problem." Representatives of Bank Clearing House Associations were invited to attend [New York Times, August 28, 1914] and to bring: “...such data as it is possible to furnish regarding the present United States cash indebtedness to Europe [including] maturing obligations, and vice versa."

Some of the most prominent bankers in the country responded to the invitation. On September $4^{\text {th }}$, the day of the conference, the New York Times reported: "Messrs. A.H. Wiggin [President of the Chase National bank] and Benjamin Strong, Jr. [President of Bankers Trust Co.] ${ }^{21}$, who will represent the New York Clearing House, carried with them to Washington data supplied by most of the international banking houses showing the amount of money owed in Europe and the amounts of credit available... It was understoood in the financial district that [Wiggin and Strong] will propose the formation of a gold pool to provide at least $\$ 200$ million in gold for shipment abroad."

The New York bankers did not disappoint. Wiggin and Strong proposed the gold pool and suggested that "the Reserve Board should name committees at the reserve centers to apportion the balance needed among the Clearing House

\footnotetext{
${ }^{21}$ The New York Times says Vice President of Bankers Trust, but Chandler [1958, p.31] notes that "Strong became President of Bankers Trust in January, 1914."
} 
Banks." The proposal had an immediate effect on foreign exchange. On September $5^{\text {th }}$ the Wall Street Journal reported: "There is a good deal easier tone to the foreign exchange market...attributed in large measure to the meeting taking place in Washington. Sterling was quoted at $\$ 5.011 / 2$, a decline of 2 cents since Thursday and 5 cents since the high this week."

The Federal Reserve Board appointed a Committee headed by James B. Forgan, president of the First National Bank of Chicago, to implement the gold pool plan. The "Forgan Committee" consisted of Benjamin Stong of New York, L.L. Rue of Philaelphia, S. Wexler of New Orleans, and T. P. Beal of Boston. Despite the wide geographic representation, Benjamin Strong dominated subsequent events. According to the New York Times, on September $10^{\text {th }}$, Strong, J.P. Morgan, Jr., and Jacob Schiff met with Treasury Secretary McAdoo for $2 \frac{1}{2}$ hours to discuss the Plan. Later that day the three New York bankers met with the Federal Reserve Board.

As these discussions proceeded, a series of fortuitous developments obviated the pressing need for the gold pool. The Wall Street Journal reported on September $15^{\text {th }}$ that: "Consummation of the plans to meet the $\$ 100$ million of New York City's maturing securities, $\$ 80$ million of which are held in England and France, was the most constructive development that has taken place since the war started...There has been evidence that England, the largest foreign holder of our securities, is not as anxious to liquidate as might be supposed. About $75 \%$ of the holders of... Lake Shore one-year notes elected to take new notes...in exchange for maturing securities. One of the bankers in charge of that financing 
said: 'When they know they can get their money, they are not so eager to have it."”

The success at rolling over maturing obligations held abroad, combined with anouncement on Septemebr $11^{\text {th }}$ (see above) that U. S. Steel experienced much less foreign liquidation during the period preceding the closing of the Stock Exchange, should have put the gold pool to rest. It also should have advanced the timetable for a resumption of trading on the NYSE. It did neither. ${ }^{22}$ Foreign exchange remained above the gold export point and that posed a danger, especially to Benjamin Strong, Jr, who was about to become a central banker.

\section{$\underline{\text { IV. Benjamin Strong, Central Banker }}$}

On October $5^{\text {th }}$, Benjamin Strong, Jr., President of Bankers Trust, was elected Governor of the Federal Reserve Bank of New York. Strong had refused the offer to become Governor of the New York Fed as recently as August $27^{\text {th }}$ (see Chandler [1958, p.38]). He reversed his decision after Henry Davison (J. P. Morgan \& Co.) and Paul M. Warburg, who had become a member of the Federal Reserve Board, spent a weekend convincing him of his public duty to accept [Chandler p.39].

None of the Federal Reserve Banks were open for business when Strong became the chief executive officer of the New York Bank. McAdoo, who had committed to opening the individual Banks before October $1^{\text {st }}$, had been preoccupied with a series of internal squabbles within the Board, ranging in

\footnotetext{
${ }^{22}$ The Wall Street Journal reported on September $14^{\text {th }}$ that the success of the New York City note sale led the 'Forgan Committee' to reduce the size of the proposed gold pool to $\$ 100$ million.
} 
substance from a philosophical dispute about the relationship between the Board and the Treasury to questions concerning appropriate quarters for Board members [McAdoo 1931, pp. 285-6]. Once Strong assumed his position in New York, McAdoo faced the most formidable obstacle to opening the banks.

As a private banker, Strong had taken an active roll in the formation of the gold pool because he believed that only gold could insure U.S. credit worthiness in Europe [Chandler, p.58]. As a central banker, Strong believed that the Federal Reserve Banks should hold far more gold than required by law. Chandler [p.83] quotes Strong as saying: "We need an immense safety factor beyond the legal minimum and it is for this reason that I have been so urgent about accumulating gold." ${ }^{23}$ Strong also wanted to make the dollar "an international currency by [creating] confidence in the redeemability of dollars in gold at all times [Chandler, p.84]."

As long as Sterling remained above the gold export point, Strong worried that the stock of gold in the U.S. would ebb towards Europe. On October $10^{\text {th }}$ he wrote to Paul Warburg: "If the Federal Reserve Banks refuse to pay gold they will be discredited at the outset, and gold will certainly be demanded of them if they expand their note issues when gold will be at a premium...the premium as reflected in the price of sterling [Chandler, p.61]." Figure 1 plots Sterling exchange rates collected from the Wall Street Journal between July 15, 1914 and

\footnotetext{
${ }^{23}$ The Federal Reserve Act required that the System hold gold reserves of 40 percent against its liabilities of Federal Reserve Notes. According to Friedman and Schwartz [1963, pp194-5]: "Since the Federal Reserve was required to keep a gold reserve of 35 percent of its deposits [reserves of member banks], it could use any excess over that amount [the 35 percent]... to meet the 40 percent requirement for notes." Strong recognized that to provide for an 'elastic currency' to meet the needs of commerce and to avoid panics, the System needed excess gold reserves.
} 
December $31,1914 .{ }^{24}$ On October $1^{\text {st }}$, Sterling sold at $\$ 4.965$ and on October $15^{\text {th }}$ it stood at $\$ 4.975$, both well above the gold export point, which was now $\$ 4.90 .^{25}$ The Wall Street Journal reported almost daily shipments of gold to Canada during October. ${ }^{26}$

McAdoo had the legislative authority to open the banks, but Strong's misgivings surely restrained him. The two had met numerous times after McAdoo's August $2^{\text {nd }}$ trip to New York, ${ }^{27}$ and Strong was not shy about articulating his views ${ }^{28}$ McAdoo also received a communication in October (see Meltzer [2003, p.74]) from Paul Warburg and W.P.G. Harding, members of the Federal Reserve Board, confirming Strong's concern that the System had very little gold. McAdoo also says [1931, p.288]: "I talked in October with the governors and chairman of most of the Federal Reserve Banks and nearly all of them thought that the necessary preparations [for opening the banks] would take considerable time."

\footnotetext{
${ }^{24}$ Figure 1 plots the exchange rate for 'demand Sterling' (rather than for cable transfers). According to Sprague [1915, p. 500]: "Demand sterling [was] the most significant single exchange rate." Ask prices for demand Sterling are used in the figure since there were fewest gaps in the data on ask quotes during this time period. The exchange rate for each date in the table comes from the Wall Street Journal of the following day.

${ }^{25}$ On October $27^{\text {th }}$ the Wall Street Journal wrote: "[a] decline in exchange below $\$ 4.90 \ldots$ shuts off gold exports. This was the gold export point since the bank of England established the gold depository in Ottawa."

${ }^{26}$ The Wall Street Journal recorded the following gold shipments to Canada during October. On the $7^{\text {th }}: \$ 523,000 ; 8^{\text {th }}: \$ 450,000 ; 14^{\text {th }}: \$ 645,000 ; 15^{\text {th }}: \$ 845,000 ; 17^{\text {th }}: \$ 1,510,000 ; 20^{\text {th }}: \$ 489,000$; $27^{\text {th }}: \$ 855,000 ; 29^{\text {th }}: \$ 760,000 ; 30^{\text {th }}: \$ 340,000$.

${ }^{27}$ In addition to the August $2^{\text {nd }}$ meeting mentioned earlier, the New York Times lists Strong at the following meetings with McAdoo: The August $13^{\text {th }}$ conference to promote U.S wheat exports, the September $4^{\text {th }}$ conference on establishing the gold pool, the $2 \frac{1}{2}$ hour meeting on September $10^{\text {th }}$, along with J.P. Morgan, Jr., and Jacob Schiff, to implement the gold pool, and a September $18^{\text {th }}$ meeting, along with Forgan, Wiggin and Rule, to modify the size of the gold pool.

${ }^{28}$ Chandler [p.3] summarizes the reasons for Strong's influence: "The strength of his personality and the force of his persuasion extended far beyond the Federal Reserve Bank of New York through the other eleven Reserve Banks, the Federal Reserve Board, [and] the United States Treasury..."
} 
Despite these objections, McAdoo felt that "the delay could not be justified." On October $25^{\text {th }}$ he announced that all Reserve Banks would open on November $16^{\text {th }}$. McAdoo quotes President Wilson [New York Times, October $27^{\text {th }}$ ] as giving the best reason for avoiding further delay: “...an effort to protect the [Federal Reserve] System against the strains of the emergency which it is designed to relieve is to cast doubt on the system itself."

McAdoo [p.289] singles out the "representative of the Federal Reserve Bank of New York (FRBNY)," in an almost comical interchange, as trying to overturn the decision:

FRBNY: "...the bank has no vault or safe place for keeping...gold" McAdoo: "There is a sub-Treasury in New York...[use] its vault." FRBNY: "Our bookkeeping system is not...ready for the printing of forms." McAdoo: "Surely you can have enough printing done by November 16..." FRBNY: "We can't get our office furniture by that time." McAdoo: "Buy a few chairs and pine-top tables."

The November $16^{\text {th }}$ date set by McAdoo held firm despite the delaying tactics of the Federal Reserve Bank of New York and its chief executive officer, Benjamin Strong, Jr. Chandler [p.61] emphasizes that Strong did not want to derail the system, as some of his fellow bankers tried to do. Strong sought the delay because "the System might be jeopardized if the Reserve banks were subjected to heavy demands when they were....weak in resources." The communication from Warburg and Harding to McAdoo mentioned above legitimizes Strong's concern about the System's shortage of gold. Chandler 
[p.65] also supports at least one additional resource shortage in New York: "the newly formed bank did, in fact, use the vaults of the New York sub-treasury."

\section{$\underline{\text { V. McAdoo's Insurance Policy }}$}

Why didn't McAdoo set a date for opening the NYSE, just as he had done for the Reserve Banks? The simplest answer is that he had stuck his neck out on August $11^{\text {th }}$ by promising to open the Federal Reserve Banks on or before October $1^{\text {st }}$. He had never said anything publicly about the Exchange, except to approve its closure on August $1^{\text {st }}$. Also, contrary to the Federal Reserve Banks, he did not have the legislative responsibility to open the NYSE. On the other hand, McAdoo surely could have used the same influence to open the Exchange as he had used to close it, ${ }^{29}$ unless he really wanted the NYSE to remain shut.

McAdoo kept the NYSE closed as his insurance policy. He worried about the fundamental risks of shifting to a new monetary regime. In his autobiography, McAdoo says [p.278]: "The entire scheme was novel and untried. We were dealing with experimental formulas, with principles that had existed only in theory and which were to be put to the most practical of tests." Chandler [p.15] emphasizes the risks by noting: "So severe were the financial strains that many questioned the wisdom of opening the Reserve Banks in November." McAdoo's concern as a prudent policymaker, combined with the Strong's arguments about gold, prevented him from doing too much too soon. He opened the Reserve

\footnotetext{
${ }^{29}$ Numerous references to Washington's influence appeared in the press, beginning with the New York Times quote of Wilson's approval of the closing on August $1^{\text {st }}$ to a Wall Street Journal article on November $16^{\text {th }}$ saying: "Despite Washington's belief in the desirability of keeping the exchanges closed, bankers ... have now entered seriously upon the consideration of ways and means to [open the Exchange]."
} 
Banks because he (and Wilson) felt they would help solve the crisis that began on August $1^{\text {st }}$. He kept the Exchange closed because he thought the financial strains were not completely gone. On November $7^{\text {th }}$ the Wall Street Journal quotes McAdoo as saying: "The chief thing that is needed [to re-open the Exchange] is a restoration of international confidence. This is, in my opinion, almost [my italics] an accomplished fact." 'Almost' was just not good enough while the Federal Reserve System was being launched.

McAdoo announced the November $16^{\text {th }}$ opening for the individual Reserve Banks on October $25^{\text {th }}$. Figure 1 shows that Sterling was above the $\$ 4.90$ gold export point throughout the month (except for a temporary decline to $\$ 4.890$ on the day after McAdoo's announcement). The Wall Street Journal continued to report gold exports to Canada (see footnote 26). Stock prices on New Street had fallen about 9 percent below July 30 closing prices as a result of war related developments (see Silber [ 2003] and Noble [1915, p.43]). Under those circumstances, the NYSE might easily have served as a teller's window (see Noble [p. 65]) for European access to our gold. Keeping the Exchange closed helped mollify Strong and sheltered the birth of the Federal Reserve System.

\section{$\underline{\text { V.1 The Risks Abate }}$}

The middle of November brought a much kinder environment for a resumption of NYSE trading. The New York Times [November $13^{\text {th }}$ ] heralded a bullish stock market by publishing, for the first time, a list of prices for 27 stocks trading on New Street. The most encouraging development, however, came from 
foreign exchange. The Wall Street Journal [November $13^{\text {th }}$ ] reported: "The foreign exchange market broke sensationally at one time to... $\$ 4.87^{1} / 2$ for cable transfers, well within the present gold export basis, which is usually considered to be $\$ 4.90$ The present level of exchange is the lowest point the market has touched since before the declaration of war, and marks the restoration of normal conditions." Figure 1 shows that Sterling remained below the gold export point after November $12^{\text {th }}$.

Henry Noble [1915, p. 74], President of the NYSE, describes a series of favorable meetings during mid-November with George Paish and Basil Blackett, representatives of the U.K. government discussing foreign exchange with Washington. They encouraged the re-opening of the Exchange at that time.

The improved conditions cast doubt on the press report of November $16^{\text {th }}$ (see footnote 29) saying that the government preferred to continue the suspension of trading on the NYSE. It turns out that the reported objection was erroneous. Noble [p.79] says that his Committee set Monday, November $23^{\text {rd }}$, as the date for restoring limited bond trading to the Exchange floor. He then notes: "On Thursday (the $18^{\text {th }}$ ) a well meaning but misguided go-between reported that he had communicated with Washington....and [they] expressed a desire to see some member of the [stock Exchange] Committee before any further steps were taken [to open the Exchange]." Noble reports [p. 80] that he contacted the 'Government official' and received a telegram explaining "that the suggestion of an interview had in no way emanated from him." 
Bond trading on the NYSE floor resumed on Saturday November $28^{\text {th }}$. Noble [p.82] says that the success with bonds encouraged the Exchange Committee to formulate a plan for 'carrying the reopening a step further.' On December 12th, stocks that were "not international in character" (see Noble [p.83]) were brought to the Exchange floor and on December 15th, all stocks were admitted for trading.

\section{$\underline{\text { Vl. Conclusion }}$}

The outbreak of World War I threatened to repeat the conditions that led to the Panic of 1907. Most of the credit for averting the crisis belongs to the Wilson Administration's speedy issuance of Aldrich-Vreeland currency. According to Benjamin Strong, private banker and central banker, the export of gold to Europe jeopardized the birth of the Federal Reserve System. Treasury Secretary McAdoo responded to the danger by encouraging the suspension of trading on the NYSE for more than four months to minimize the outflow of gold and to smooth the way for the new monetary system. On August 28, 1914, the Wall Street Journal got it almost right when it said: "To put it frankly, the bankers closed the Stock Exchange and the bankers will reopen it, after wise counsel with the Federal Reserve Board." 


\section{References}

Chandler, Lester V., 1958, Benjamin Strong, Central Banker, Washington, D.C., The Brookings Institution

Friedman, Milton, and Anna Jacobson Schwartz, 1963, A Monetary History of the United States, Princeton, Princeton University Press.

Keynes, John Maynard, 1915, "War and the Financial System, August 1914," Economic Journal, Volume 24, No. 95, pp. 460-486.

McAdoo, William Gibbs, 1931, Crowded Years, Boston, New York, Houghton Mifflin company.

Michie, Ranald C., 1999, The London Stock Exchange: A History, Oxford, Oxford University Press.

Meltzer, Allan H., 2003, A History of the Federal Reserve, Volume I, 19131951, Chicago, University of Chicago Press

Nelson, Samuel Armstrong, 1907, The Consolidated Stock Exchange of New York, New York, The A. B. Benesch Co.

New York Times, 1914, 1915, Various Issues.

Noble, Henry George Stebbins, 1915, The New York Stock Exchange in the Crisis of 1914, Garden City, N. Y., The Country Life Press.

Silber, William L. 2003, "What Happened to Liquidity When World War I Shut the NYSE?" NYU Salomon Center Working Paper No. S-03-13.

Sobel, Robert, 1968, Panic on Wall Street; a History of America's Financial Disasters, New York, Macmillan.

Exchange, 1921-1971, New York, Weybright and Talley.

$$
\text { 1972, Amex: A History of the American Stock }
$$

Sprague, Oliver Mitchell Wentworth, 1910, History of Crises Under the National Banking System, Washington, D.C., Government Printing Office.

,1915, "The Crisis of 1914 in the United States," American Economic Review, Volume 5, No. 3, pp. 499-513. 
Wall Street Journal, 1914, 1915, Various Issues.

Yeager, Leland B. 1966, International Monetary Relations: Theory History, and Policy, Harper \& Row, New York. 
Table 1: Selected Closing Prices for Stocks on July 31, 1914 and July 30, 1914

\begin{tabular}{|c|c|c|c|c|}
\hline \multirow{2}{*}{$\begin{array}{c}(1) \\
\text { Stock }\end{array}$} & \multicolumn{2}{|c|}{ (2) } & \multicolumn{2}{|c|}{ (3) } \\
\hline & $\begin{array}{l}\text { July } 31 \\
\text { Close }\end{array}$ & $\begin{array}{l}\text { Percent } \\
\text { Change }\end{array}$ & $\begin{array}{l}\text { July } 30 \\
\text { Close }\end{array}$ & $\begin{array}{l}\text { Percent } \\
\text { Change }\end{array}$ \\
\hline American Smelting & $521 / 2$ & - & $521 / 2$ & $-13.0 \%$ \\
\hline Chicago, Milwaukee \& St. Paul & 87 & $+2.1 \%$ & $851 / 4$ & $-7.8 \%$ \\
\hline Reading Railroad & 141 & $+.7 \%$ & 140 & $-9.2 \%$ \\
\hline Union Pacific & $1131 / 2$ & - & $1131 / 2$ & $-5.4 \%$ \\
\hline U.S. Steel & $511 / 8$ & $-1.4 \%$ & $517 / 8$ & $-8.6 \%$ \\
\hline Western Union & 51 & $-4.4 \%$ & $533 / 8$ & $-6.2 \%$ \\
\hline
\end{tabular}

Source: New York Times, August 1, 1914 


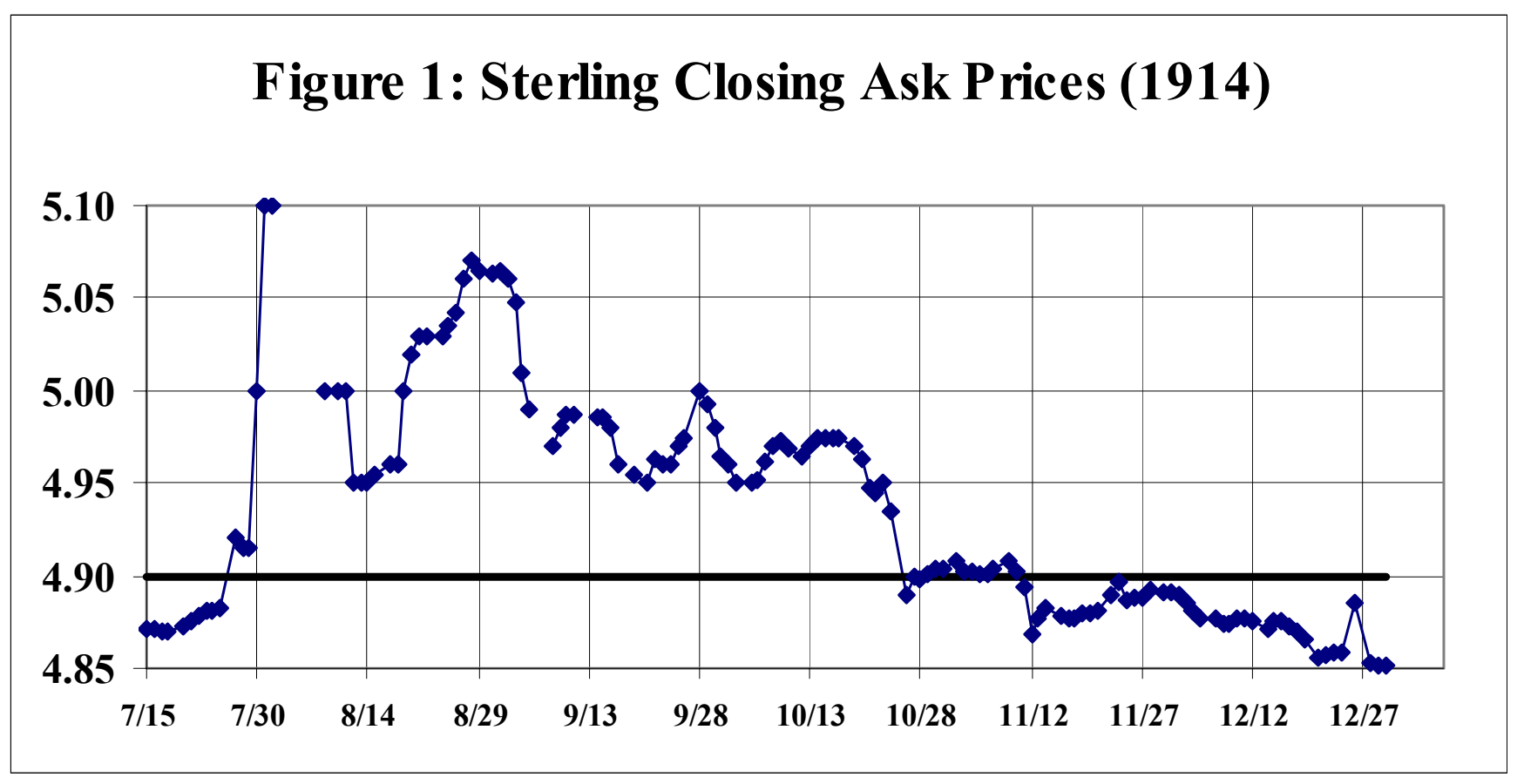

Source: Wall Street Journal, July 15, 1914 through December 31, 1914 